known, and, without doubt, consists of two atoms of phosphorus, united with five atoms of oxygen, whereas Berzelius only found three atoms of exygen to two of the rare metal in vanadic acid. How is this discrepancy to be explained? We have here to do either with an exception to the otherwise general law of isomorphism, so that we may have identity of crystalline form, without any analogy in chemical composition, or Berzelius's experiments and conclusions respecting the constitution of this vanadic acid are incorrect. By experiments on the properties of vanadium and its compounds, made with much larger quantities than it fell to the lot of the Swedish chemist to work with, it was shown that something had been overlnoked by him. It was proved that the substance which he supposed to be a metal was not a metal at all, but an oxide, and that vanadic acid really contains more oxygen than he believed it to contain. And what is remarkable is that this quantity of oxygen, which had been overlooked, is exactly the quantity which is needed in order to make the constitution of vanadic acid identical with that of phosphoric acid. We have to take out of each atom of Berzelius's metal one atom of oxygen in order to get the true vanadium, so that the real atomic weight of this element is less than that giren to it by Berzelius by the atomic weight of oxygen, $67^{\circ} 3-16=5 \mathrm{r} \cdot 3$. Thus the chemical constitutions of phosphoric and of vanadic acids are represented by the formule $\mathrm{P}_{2} \mathrm{O}_{5}, \mathrm{~V}_{2} \mathrm{O}_{5}$. The law of isomorphism remains unassailed, and the goddess (Vanadis is a cognomen of the Scandinavian goddess Freia) who was found wandering as a waif and a stray amongst her companion elements, has been restored to her natural friends, and now forms a recognised member of a family group.

To sum up, my aim in the foregoing remarks has been to show that if freedom of inquiry, independence of thought, disinterested and steatfast labour, habits of exact and truthful observation, and of clear perception, are things to be desired as tending to the higher intellectual development of mankind, then original research ought to be encouraged as one of the most valuable means of education. And that on this ground alone, and independent of the enormous material benefits which such studies confer on the nation, it is the bounden duty not only of the Guvernment, but of every educational establislnnent, and of every citizen of this country who has the progress of humanity at heart, to promote and stimulate the growth of original research amongst us.

\section{HELVETIC SOCIETY OF NATURAL SCIENCES}

TIIE fifty-sixth annual meeting of this society was held on the ISth, Igth, and 2oth of August last, at Schaffhouse, under the presidency of Dr. Stierlin, and is described as having been a highly animated one. We shall note a few of the more im. portant papers presented; for particulars of which we are indebted to the Archives des Sciences.

In the section of Physics and Chemistry, M. Soret described a method for studying ultra-violet spectra. It consists in placing a thin fluorescent lamina (sulphate of quinine, e.g. between two glass plates) before the eyepiece of a spectroscope, where the image is formed, and observing, with sufficient inclination of the eyepiece the image of the ultra-violet spectrum then developed on the lamina. Prof. Kopp read a paper on bresiline and its derivatives. The Deacon process of manufacturing chlorine was the subject of a papar by M. IIurter, which gave rise to lively dis. cussion. Dr. Heim, who has been observing the sounds of cascades, find they all give the note $C$ sharp, or $F$.

In Geology, Dr. Schalch had a paper on the volcanic rocks of Höh yau. These are in two groups, that of basalts, and that of phonolites. They form isolated cones surrounded with thick deposits of volcanic tufa, the nature and arrangement of which indicate that the eruptions ha ppened at successive intervals about the end of the tertiary epoch. M. Favre showed a section of the Vaudois Alps made at Pleiades, near Vevey aux Ormonts; in which he distinguishes three zones, consisting of superior Jurassic and Necomian, and different portions of Eocene, strata. Mr.Heim exhibited a new method of geological representation of a country; it consists in a series of sections, on the same scale, coloured and fixed vertically at equal distances on a geological map. Ife also made some observations on the zone of contact of crystalline rocks and sedimentary strata in Eastern Switzerland and the Bernese Alps. M. Lang announced the early publication, by the Alpine Club of a glacier-register, in which information will be given as to dimensions, form progress, \&c., of glaciers. At the first general séance Prof. Heim gave a valuable resume of the various theories of glacial motion. At the second, Prof. Desor presented a memoir on morainic landscapes, by which he denotes those indicating a former extension of glaciers. The most striking types are at the southern base of the Alps. There is discernible a zone consisting of a succcssion of verdant hillocks, sometimes aligned, sometimes separate; these are found to be composed of the débris of old formations bruised and triturated, and clearly indicating glacial action. A good example occurs at the base of Monte Campo di Fiori.

At the general opening siance Prof. Forel gave an account of his researches on the deep-water fauna in Lake I eman, of which he enumerates some thirty species. If had also studied the fauna of the lakes of Neuchatel, Zurich, and Constance. His conclusions are briefly these:- There are in the lal es three distinct fauna: $(a)$ a littoral, extending to 15 or 20 metres depth ; (b) a deep, fauna, from 20 to 300 metres; and (c) a pelagic fauna. All the forms of the deep fauna have analogous or similar forms in the littoral fauna ; but the converse does not hold, At the same level the deep fauna are the same. A few species found between 30 and 100 metres are not found at 300 metres. but all the types at 300 metres are found between 30 and 100 metres. There are local and seasonal differences. The deep fauna are best studied between 30 ani 60 metres. In comparing different lakes the general characters of deep fauna are the same, but special characters vary.

In the section of zoolngy and botany, MI. Bugnion described some sensitive organs found in the epidermis of Proteus and Axolotl. They are considerably developed in the former (1460 were counted in one specimen), and are disposed in linear groups of three or four along certain nerves of the head, and the lateral nerve to the end of the tail. They resemble the cyathiform rrgans discovered by $\mathrm{MI}$. Leydig in $\mathrm{I} S 5_{\mathrm{O}}$, in the epidermis of fishes. Dr. Cartier gave a paper on the sensitive hairs of crocodiles.

In the medical department Prof. Karsten, of Vienna, made a communication on necrobiosis in which he pointed out that Bacteria, Vibriones, and micro-coceus, \&s., are not to be re sarded as organic species, properly so called; the phenomena of animal reproinctlon lave never becn observed in them. They are pathor logical products, which grow in the interior of vegetable or animal cells, but which do not penetrate these when once developed, as parasites.

In the department of Pure Mathematics the principal paper was by Prof. Schwarz on a new example of a continual function which does not admit of derivatives. This paper will be found in crtenso in the Archives.

This is the third time in its history that the Helvetic Society has met at Schafflouse, the former occasions having been in IS25 and I 847 . The next annual session is to be held at Coire.

\section{SCIENTIFIC SERIALS}

Sitzungsberichte der Königl. Böhmischen Gesellschaft der Wissenschaften in Prags. Jan. IS71 to June I872. (3 numbers). -Among the more valuable matter in these numbers may be noted some contributions to palxontological botany; more especially a paper by MI. Feistmantel describing the various fruit-forms met with in Bohemian coal formations. (As published separately, the paper contains several excellent plates). The same author communicates also full accounts of the flora in coal-measures at the foot of the Riesengebirge, and at Merklin. -M. Dvorak describes some curious experiments on individual differences between the two eyes, and between different parts of the retina of the same eye. He shows that two non-simultaneous impressions, each affecting one eye, appear simultaneous, when the time.interval is of a certain length; this interval he measures with suitable apparatus. - In chemistry we have a note by Prof. Stolba, giving a new method of preparing borofluoride of potassium, and an account of the properties of this substance.Dr. Weyr investigates mathematically the distance-action of electrical sclenoids on material plane surlaces; and a note by M. Domalip furnishes experimental proof of certain laws deduced by M. Dub as to the dependence of magnetic moment on the dimensions of a magnetic bar. - There are also papers on the fauna of lakes in the Böhmerwald, on basaltic formaticns, and on several points in mineralogy and pure mathematics.

Bullctin ae l'Acadimie Royalc de Bilsiqui, No. S, I873.-In this number is described a recording metiorograph, devised by II. Van Rysselberghe, and which seems to have some merit; 
the advantage being that the readings of scveral different instruments can be recorded by means of a single steel graver, making traces on a vamished copper sheet. The sheet is fixed on a vertical cylinder, which rotates at equal intervals (e.g. every ten minutes) an electric circuit of which the instrument to be observed forms part, is closed by the movement of the cylinder; this liberates the graver, which then gives a tracing proportional, in length, to the indication of the instrument. At exch revolution the graver descends a little; thus a serics of equidistant lines are obtained, the extremities of which form the curve of observations. The copper sheet is afterwards dipped in an acid and thus made ready for engraving.-M. Terby communicates some drawings made by MI. Schroeter, in the end of last century, which show the configuration of the spots of Mars at that time. He finds, in these, fresh proof of the permanence of the spots. $A$ letter from Prof. Genocchi, of Turin, on several mathematical questions, calls forth a long report from MI. de Tilly with refercnce to the alleged impossibility of demonstrating the postulates of Euclid by plane geometry, or by any geometrical reasoning.-Ve further find notes on the congelation of alcoholic liquids, (Melsens), on the motion of projectiles, on hypo-sulphurous acid, on some storms at Aartselaer in July, and other topics.

Bulletin de la Sociáts Impíriale des Naturalistes de Noscout, No. I, 1873. - In this number there is a valuable paper of spectroscopic solar observations in 1872 , by M. Bredichin Four plates are appended, showing the spectroscopic profile of the sun from July 22 to September Io. The author's results confirm, in the main, those of Secchi.-M. Berg gives some particulars as to the successful acclimatisation of a Japan silkworm, the $A n$ therea Yama MFayu, in the Baltic provinces. Cultivators were looking in this direction partly because of the difficulty of acclimatising mulberry in the north; the new animal feeds on oak leaves. One striking fact is, that some of the eggs were ex. posed, at times, for three days successively, to a temperature of $12^{\circ}$ R., without apparent injury. The temperature at which the worms were kept after leaving the egg till spinning time, varied between $12^{\circ}$ and $16^{\circ} \mathrm{R}$. The entire extra-oval if ef the Yama Mayu in Riga is about $16 \mathrm{l}$ weeks ; or 9 in the caterpillar, 6 in the chrysalis, and $I_{2}^{1}$ in the moth stages respectively. Experiments, extending over three years, lave fully shown that the scheme in question is a practicable one. We have further to note $a$ long and interesting account, by M. Wolkenstein, of certain ancient cemeteries named "Jalnikis," found on many of the hill-sides in Novgorcd. The tombs are made of unhewn stones arranged in form of a rectangular cyst, which contains the skeleton. In his study of the question whether these cemeteries belonged to ancient Novgorodians, or some other people, the author is led to assign a Slavic origin.-Among the remaining papers are a note by M. Stepanoff on the development of Calyptrea, and a reply by M. Lubimoff to M. Bredichin.

Rale Istituto Lombardo di Scientze Lettere Rendiconti Fascicolo, XV, 1873. - In addition to a large quantity of historical and philosophical matter, which includes a fourth paper on Kant's philosophy, by C. Cantoni, this number contains observations of Comet II, I 873 , by S. Tempel; a long paper on the polymorphism of Pleospora Herbarim, by Drs. Gibelli and Griffini ; and also some anatomical and medical notices.

TuE Annali di Chimica apflicata alla meticina for September contains the usual number of notices on pharmaceutical preparations, \&c.

American Fournal of Science and Arts, October.-This number contains a description of some valuable improvements in the silt analysis of soils and clays, by Mrr. Hillgard. From minute observations on the working of the elutriating apparatuses of Nöbel, Schulze, Fresenius, and others, he concludes that all determinations hitherto made with conical vessels are vitiated by irregular currents, and a kind of miniature avalanche formed by the particles, He employs a cylindrical elutriating tube, having a rotary chum attached to its base, but screened by wire from the liquid column. This has given good results.Prof. Dana has a (continued) paper on the quartzite, limestone, and associated rock of the vicinity of Great Barrington, Berkshire Co., Mass.-MIr. May describes some experiments on the determination of lead as peroxide, and Mrr. Remsen communicates a note on isomeric sulpho-salicylic acids.-Mr. Bentham's anniversary address to the Linnean Society is given; also a French Academy notice of Dr. Verneuil, who did valuable service to North $A$ merican geology. - IVe further note accounts of zarious survey operations in Colorado, Sierra Nevada, Utah, \&c.
Atti della Rale Academia dei Lincei Roma, Dec. 1872. This publication contains, among other papers, an interesting description, accompanied with plates, of certain hum 1 bodies found in a remarkable state of preservation in a cemetery at $\mathrm{Fe}$. rentillo. The authors, MMI. Naggiorani and Moriggia, made analyses of the soil, which abounded in salts of lime having, of course, avidity for water. The ground was porous, and readily permitted passage of vapour from one stratum to another. Scarcity of humus and good ventilation were other favouring causes. There was a popular tradition that the soil was brought from Palestine, but this is thought incorrect. The mummies were throurhout invaded with sporulac and various other para. sites, which doubtless contributed to the mummification.-A long paper by M. Volpicelli offers a complete and general solution, through the geometry of situation, of the problem relating to the course of a horse over a checkered surface.-Prof. Cantoni has an article on the various modes of electrical testing (esplorazionz) and on the influence of hypothesis in electrostatics; in which he makes some strictures on certain passages in Tyndall's little work on Electricity, referring to the existence of two fluids. - We further notice a paper by Prof. Cadet on the functions of the white nerve substance, and one by Prof. Respighi on the shower of falling stars observed November 28, I 872 .

\section{SOCIETIES AND ACADEMIES \\ PARIS}

Academy of Sciences, Oct. 20.-MI. de Quatrefages, president, in the chair. - The following papers were read :-Theory of the movement of a point attracted towards a fixed centre, by M. J. Bertrand.-On Dr. Reye's explanation of the solar sfots, by M. Faye. Dr. Reye considers that the heat of a facula causes an up-rush and expansion of the superincumbent atmosphere, causing a sort of vortex through which the materials of lower strata rise, expand, cool down, and condense. MI. Faye, after explaining the theory in question, argued that a very simple fact overthrows it at once. Dr. Reje's theory would make the vortex or spot on the sun, while the measurements of Carrington have shown that it is really in the sun.--Anatomical researches on the tardigrade Edentata, by M. P. Gervais.-M. Alph. de Candolle presented the last vulume of the "Prodromus Syste. matis Naturalis Regni Vegetabilis."-The secretary reported on a number of papers on the Phylloxera.--Researches on an easy method of measuring the capacity of ships, by M. d'Arout. Additional note to the monograph on the fish of the family of the Symbranchida, by M. C. Dareste.-On the production of galls on vines attacked by the Phylloxera, by M. Max Cornu.-On the reproduction of the oak P/tylloxera, by M. Balbiani.-On the production of certain crystalline borates in the dry way, by M. A. Ditte. The paper in question described several borates of barium and magnesium, and also several double salts of the same class. - Note on the chlorovanadates, by M. P. Haute. feuille, - On the production of methylamines in the manufacture of pyroligneous products.

\section{CONTENTS} PAGE

Our Natronal Museuns . * * • * * * * * * * 543

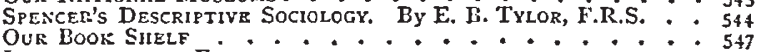

LETTERS TO THE EDITOR:-

Remarkable Phenomena.-H. C. Russelt, Government Astronomer $5 \ddagger 7$ Periodicity of Rainfall -C. MELDKUM

Dr. Sanderson's Expuriments and Archebiosis.-Dr. H. Cirarlto

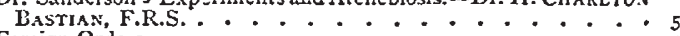

Foreign Orders Mr. Forbes on Mrallet's Theory of Volcanic Eruption.-RoserT MIALLET, F.R.S

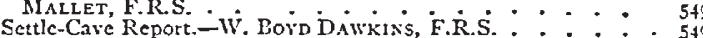

The Oxford Science Fellowships-The Cambride i. JoIn PeRRY

Simple Diffraction Experiment

Publication of Learned Societies" Transactions-iv $b^{\circ}$ Gices $\cdot 55^{\circ}$

Examinations of the Sciexce and Art Department in Blology 550

ON THE SCIENCE OF WeighiNg aNd MIEASURING, AND tIIE STANDARDS OF IVEIGHT AND MEASURE, VII. By H. W. Chisholm, Warden of the Standards (IVit/t Illustrations)

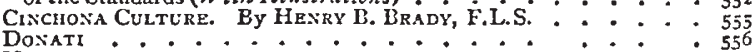

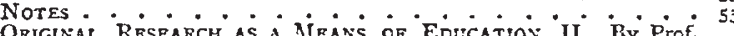

Roscor F.R.S. . . . . . . . . . . . .

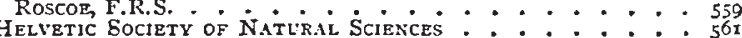

Helvetic Sochety of Natlral Sciences . - . - . . . 561

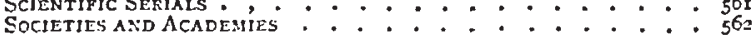

